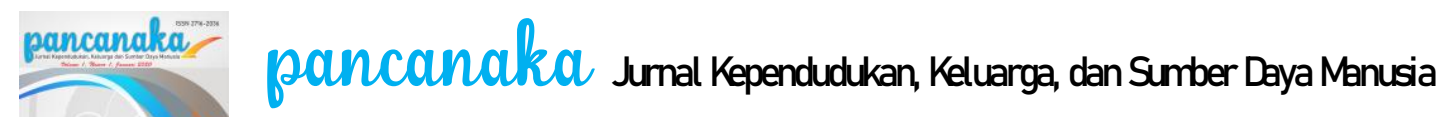

Volume 1, No. 1, Tahun 2020, 55-64

ISSN 2716-2036 (Online)

DOI 10.37269/pancanaka.vli1.9

\title{
AKSELERASI PENINGKATAN KUALITAS PENDIDIKAN DAERAH TERTINGGAL MELALUI MODEL PEMBELAJARAN HIGHER ORDER THINKING SKILL (HOTS) DI ERA INDUSTRI 4.0
}

\author{
Priyono, Kementerian Desa, Pembangunan Daerah Tertinggal dan Transmigrasi. \\ E-Mail: priyohamidjodjo@gmail.com
}

Evy Khuriyana, Kementerian Desa, Pembangunan Daerah Tertinggal dan Transmigrasi.

E-Mail: evy.khuriyana@gmail.com

\begin{abstract}
Abstrak
Kesetaraan pendidikan merupakan salah satu persoalan utama pendidikan di daerah tertinggal. Tidak hanya terkait aksesibilitas dan minimnya sarana dan prasarana, namun ketersediaan tenaga pendidik dan kualitas belajar mengajar juga perlu mendapatkan perhatian. Pemerintah melalui Kementerian Desa, Pembangunan Daerah Tertinggal dan Transmigrasi menginisiasi percepatan peningkatan kualitas pendidikan di tingkat SMP daerah tertinggal. Rintisan model pembelajaran berorientasi Higher Order Thinking Skill (HOTS) dilakukan bersama pihak mitra yang telah mengembangkan pembelajaran menggunakan materi belajar digital. Penyampaian materi pelajaran dapat secara online dan offline, mudah disesuaikan dengan kondisi daerah pedalaman yang sulit mengakses fasilitas internet. Implementasi pilot project di kabupaten yang masih berstatus daerah tertinggal, Halmahera Barat, melibatkan 2 rombongan belajar siswa kelas IX A dan IX B, SMPN 7 Halmahera Barat. Metode yang digunakan dalam pengkajian ini yaitu kuantitatif eksperimen dengan melihat hasil belajar siswa yang diukur dari nilai pre-test dan post-test yang dilakukan terhadap kelas eksperimen dan analisis data dilakukan dengan uji-T paired test. Hasil kajian menunjukkan bahwa terdapat peningkatan hasil belajar siswa secara signifikan ( $t_{\text {hitung }}>t_{\text {tabel }}$ ). Implementasi metode pembelajaran berbasis HOTS dengan fasilitas materi belajar digital dapat direplikasi untuk daerah tertinggal dan terpencil yang masih kurang ketersediaan tenaga guru dan sebagai bentuk antisipasi penyiapan sumber daya manusia era Industri 4.0.
\end{abstract}

Kata Kunci : daerah tertinggal, higher order thinking skill (HOTS), industri 4.0.

\begin{abstract}
Educational equality is one of the main problems faced in the disadvantaged regions in Indonesia. Not only related to the lack of accessibility, facility and infrastructure, but also the availability of teacher as well as the quality of teaching and learning, which also need attention. The Government of Indonesia through the Ministry of Villages, Development of Disadvantaged Regions and Transmigration has initiated an acceleration of the quality improvement of education at the junior secondary level in the disadvantaged regions. The pioneering learning model oriented to Higher Order Thinking Skill (HOTS) was conducted with partners who had developed learning using digital learning materials. Submission of subject matter can be online and offline, easily adapted to rural conditions that are difficult to access internet facilities. Implementation of the pilot project in West Halmahera, as one of the disadvantaged regions, involved two groups of IX A and IX B class students, SMPN 7 in West Halmahera. The method used in this study is a quantitative experiment, by looking at student learning outcomes measured from pre-test and post-test scores conducted on the experimental class and data analysis is done by paired T-test. The results of the study showed that there was a significant increase in student learning outcomes ( $t$ hitung $>t_{\text {table }}$ ). The implementation of HOTS-based learning methods with digital learning material facilities can be replicated for other disadvantaged regions in Indonesia, as an alternative solution to support the acceleration of educational development. Adoption of the HOTS digital based learning method also support the preparation of human resources anticipating the Industrial Revolution 4.0 era.
\end{abstract}

Keywords : underdeveloped regions, higher order thinking skill (HOTS), industri 4.0. 


\section{Pendahuluan}

Kesenjangan kualitas pendidikan antara pusat dan daerah di Indonesia masih sangat tinggi. Rendahnya kualitas pendidikan di daerah tertinggal umumnya diakibatkan oleh beberapa faktor diantaranya sangat minimnya aksesibilitas sarana prasarana pendidikan dan kurangnya tenaga guru untuk menunjang proses belajar mengajar. Persoalan pendidikan bukan hanya masalah terbatasnya akses dan minimnya sarana prasarana pendidikan juga masalah sangat kurangnya ketersediaan guru karena tidak meratanya distribusi guru. Dilihat dari aspek kecukupan kuantitas, kekurangan tenaga guru sebenarnya diindikasikan karena kurang meratanya sebaran/ distribusi penugasan guru. Di sekolah-sekolah wilayah dekat perkotaan/ dekat ibukota kabupaten biasanya jumlah guru cukup memadai, sebaliknya sekolah-sekolah di wilayah tertinggal dan terpencil biasanya sangat minim tersedia guru. Permasalahan semakin kompleks bila dilihat kualitas dan kinerja guru yang ada dalam mendukung proses belajar mengajar untuk mencapai target belajar yang berkualitas. Berdasarkan data lapangan dari Direktorat Jenderal Pembangunan Daerah Tertinggal Kementerian Desa Pembangunan Daerah Tertinggal dan Transmigrasi (Ditjen PDT Kemendesa PDTT) Halmahera Barat merupakan salah satu kabupaten di Maluku Utara yang sampai tahun 2019 ini masih masuk ke dalam status 122 kabupaten tertinggal di Indonesia. Indeks Pembangunan Manusia (IPM) Halmahera Barat tahun 2018 adalah 64,54 jauh tertinggal dari rata-rata IPM nasional yaitu 71,39. Distribusi guru juga tidak merata masih banyak berada di di Kecamatan Jailolo yang merupakan Ibukota kabupaten. Berdasarkan indikator ketertinggalan, prioritas ketertinggalan di Halmahera Barat adalah rendahnya kualitas sumber daya manusia.

Upaya terobosan pengembangan pendidikan berbasis teknologi informasi berpeluang membantu solusi permasalahan rendahnya kualitas pendidikan tersebut. Salah satu inovasi di bidang pengembangan metode pembelajaran siswa Sekolah Menengah Pertama adalah melalui fasilitas media belajar digital (e-learning) dengan model pembelajaran yang berorientasi High Order Thinking Skills (HOTS). Keterampilan berpikir tingkat tinggi (Higher Order Thinking Skills) merupakan suatu keterampilan berpikir yang tidak hanya mengandalkan kemampuan mengingat, tetapi membutuhkan kemampuan lain yang merupakan hasil dari proses pembelajaran yang telah dilakukan oleh guru untuk meningkatkan efektivitas kegiatan pembelajaran. Selain itu, model pembelajaran HOTS ini lebih mendorong siswa untuk berfikir kritis, kreatif, aktif dan memotivasi siswa untuk untuk mengembangkan kemampuannya secara maksimal.

Implementasi pengembangan metode pembelajaran siswa yang berorientasi HOTS berbasis e-learning melalui penerapan inovasi teknologi informasi memungkinkan sebuah terobosan yang memberikan solusi dalam upaya peningkatan kualitas pendidikan di daerah tertinggal. Percepatan peningkatan prestasi hasil belajar siswa di daerah tertinggal dapat dilakukan walaupun dengan kendala kurangnya fasilitas sarana dan prasarana serta minimnya ketersediaan guru. Keterjangkauan layanan pendidikan dasar dapat diperluas untuk memberikan dampak pencapaian target peningkatan angka harapan sekolah. Dampak dan outcome nya diharapkan berperan signifikan dalam penyediaan sumber daya manusia berkualitas sebagai prasyarat mengantisipasi era Industri 4.0 dan society 5.0.

Ditjen PDT Kemendesa PDTT dalam beberapa tahun terakhir telah menggalang kerja sama dengan berbagai mitra di bidang pendidikan. Setidaknya ada 60 pihak pengembang sistem aplikasi digital pemula (start-up) yang digandeng untuk membantu peningkatan kualitas pendidikan, kesehatan, dan peningkatan ekonomi dalam mendukung percepatan pengentasan daerah tertinggal. Salah satu mitra start up yang bergerak di bidang pendidikan mengembangkan media belajar berbasis digital (e-learning) yang dapat diakses secara online dan offline untuk dapat diimplementasikan di SMP yang ada di kabupaten Halmahera Barat dalam rangka mendukung upaya percepatan peningkatan kualitas pendidikan daerah tertinggal. 
Dari implementasi metoda pembelajaran dan pemberian pendampingan guru yang dibekali skill tentang HOTS di SMP Halmahera Barat akan dianalisis apakah ada peningkatan hasil belajar siswa sebelum implementasi dan setelah implementasi (pre-test dan post test) dan juga mengetahui seberapa signifikan peningkatan yang terjadi sebagai salah satu cara untuk mengukur keberhasilan implementasi metode pembelajaran yang diterapkan.

\section{Kajian Pustaka}

Era revolusi industri 4.0 mengubah konsep pekerjaan, struktur pekerjaan dan kompetensi yang dibutuhkan dunia pekerjaan. Dalam survey salary tahun 2018, perubahan fokus transformasi bisnis ke platform digital telah memicu permintaan profesional Sumber Daya Manusia (SDM) yang memiliki kompetensi yang jauh berbeda dari sebelumnya (Walters, 2018). Selain itu, era industri 4.0 juga telah mengubah cara pandang tentang pendidikan. Perubahan yang dilakukan tidak hanya mengenai cara mengajar, tetapi jauh yang lebih esensial, yaitu perubahan cara pandang terhadap konsep pendidikan itu sendiri. Pendidikan setidaknya harus mampu menyiapkan anak didiknya menghadapi tiga hal: a) menyiapkan anak untuk bisa bekerja yang pekerjaannya saat ini belum ada; $b$ ) menyiapkan anak untuk bisa menyelesaikan masalah yang masalahnya saat ini belum muncul, dan c) menyiapkan anak untuk bisa menggunakan teknologi yang sekarang teknologinya belum ditemukan (Ristekdikti, 2018). Untuk bisa menghadapi tantangan tersebut, syarat penting yang harus dipenuhi adalah bagaimana menyiapkan kualifikasi dan kompetensi guru yang berkualitas.

Era revolusi industri 4.0 merupakan tantangan berat bagi guru Indonesia. Jack Ma dalam World Economic Forum (Fonna, 2019) mengemukakan pendidikan adalah tantangan besar abad ini. Jika tidak mengubah cara mendidik dan belajar-mengajar, 30 tahun mendatang kita akan mengalami kesulitan besar. Revolusi industri 4.0 juga akan berdampak pada peran pendidiknya. Jika peran pendidik masih mempertahankan sebagai penyampai pengetahuan, maka mereka akan kehilangan peran seiring dengan perkembangan teknologi dan perubahan metode pembelajarannya. Kondisi tersebut harus diatasi dengan menambah kompetensi pendidik yang mendukung pengetahuan untuk eksplorasi dan penciptaan melalui pembelajaran mandiri. Tantangan yang baru menuntut proses terobosan pemikiran (breakthrough thinking process) apabila yang diinginkan adalah output yang bermutu yang dapat bersaing dengan hasil karya dalam dunia yang serba terbuka.

Dalam konteks pembelajaran abad 21, pembelajaran yang menerapkan kreativitas, berpikir kritis, kerjasama, keterampilan komunikasi, kemasyarakatan dan keterampilan karakter, tetap harus dipertahankan, sebagai lembaga pendidikan peserta didik tetap memerlukan kemampuan teknik. Pemanfaatan berbagai aktifitas pembelajaran yang mendukung industri 4.0 merupakan keharusan dengan model resource sharing dengan siapapun dan dimanapun, pembelajaran kelas dan laboratorium dengan augmented dengan bahan virtual, bersifat interaktif, menantang, serta pembelajaran yang kaya isi bukan sekedar lengkap. Partnership for 21st Century Learning (Fadel, 2008) mengembangkan framework pembelajaran abad 21 yang menuntut peserta didik memiliki keterampilan, pengetahuan dan kemampuan dibidang teknologi, media dan informasi, keterampilan pembelajaran dan inovasi serta keterampilan hidup dan karir. Framework ini juga menjelaskan tentang keterampilan, pengetahuan dan keahlian yang harus dikuasai agar siswa dapat sukses dalam kehidupan dan pekerjaannya. Sebagaimana Gambar 1. 


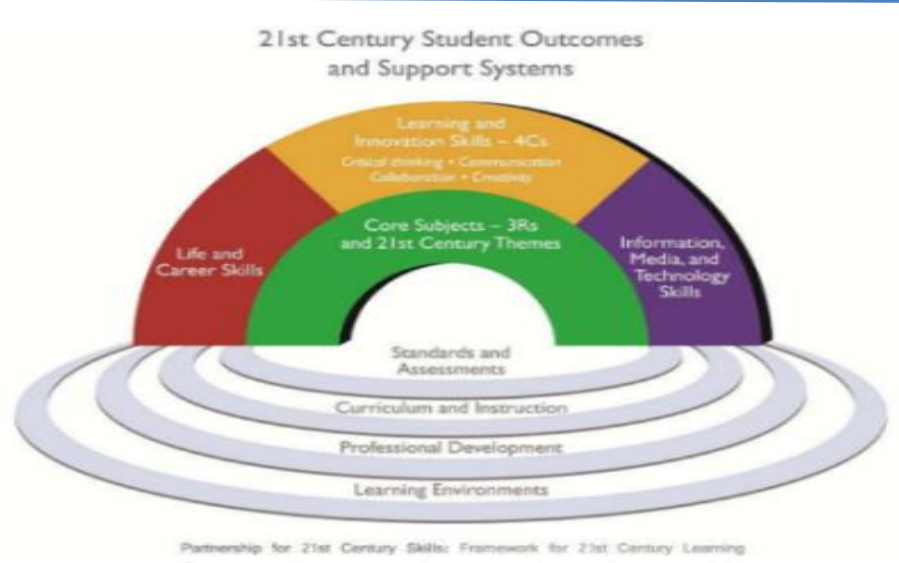

Gambar 1. Framework Pembelajaran Abad 21

Sejalan dengan hal itu, Litbang Kemendikbud (Direktorat Pembinaan SMK Kementerian Pendidikan dan Kebudayaan, 2018) merumuskan bahwa paradigma pembelajaran abad 21 menekankan pada kemampuan peserta didik dalam mencari tahu dari berbagai sumber, merumuskan permasalahan, berpikir analitis dan kerjasama serta berkolaborasi dalam menyelesaikan masalah. Adapun penjelasan mengenai framework pembelajaran abad ke-21 menurut BSNP adalah sebagai berikut: (a) Kemampuan berpikir kritis dan pemecahan masalah (Critical-Thinking and Problem-Solving Skills), mampu berfikir secara kritis, lateral, dan sistemik, terutama dalam konteks pemecahan masalah; (b) Kemampuan berkomunikasi dan bekerjasama (Communication and Collaboration Skills), mampu berkomunikasi dan berkolaborasi secara efektif dengan berbagai pihak; (c) Kemampuan mencipta dan membaharui (Creativity and Innovation Skills), mampu mengembangkan kreativitas yang dimilikinya untuk menghasilkan berbagai terobosan yang inovatif; (d) Literasi teknologi informasi dan komunikasi (Information and Communications Technology Literacy), mampu memanfaatkan teknologi informasi dan komunikasi untuk meningkatkan kinerja dan aktivitas sehari-hari; (e) Kemampuan belajar kontekstual (Contextual Learning Skills), mampu menjalani aktivitas pembelajaran mandiri yang kontekstual sebagai bagian dari pengembangan pribadi, dan (f) Kemampuan informasi dan literasi media, mampu memahami dan menggunakan berbagai media komunikasi untuk menyampaikan beragam gagasan dan melaksanakan aktivitas kolaborasi serta interaksi dengan beragam pihak. Keterampilan berpikir tingkat tinggi yang dalam bahasa umum dikenal sebagai Higher Order Thinking Skill (HOTS) dipicu oleh empat kondisi.

a. Sebuah situasi belajar tertentu yang memerlukan strategi pembelajaran yang spesifik dan tidak dapat digunakan di situasi belajar lainnya.

b. Kecerdasan yang tidak lagi dipandang sebagai kemampuan yang tidak dapat diubah, melainkan kesatuan pengetahuan yang dipengaruhi oleh berbagai faktor yang terdiri dari lingkungan belajar, strategi dan kesadaran dalam belajar.

c. Pemahaman pandangan yang telah bergeser dari unidimensi, linier, hirarki atau spiral menuju pemahaman pandangan ke multidimensi dan interaktif.

d. Keterampilan berpikir tingkat tinggi yang lebih spesifik seperti penalaran, kemampuan analisis, pemecahan masalah, dan keterampilan berpikir kritis dan kreatif.

Definisi keterampilan berpikir tingkat tinggi menurut Resnick dalam (Fonna, 2019) adalah proses berpikir kompleks dalam menguraikan materi, membuat kesimpulan, membangun representasi, menganalisis, dan membangun hubungan dengan melibatkan aktivitas mental yang paling dasar. Keterampilan ini juga digunakan untuk menggarisbawahi berbagai proses tingkat tinggi menurut jenjang taksonomi Bloom. Bloom mengemukakan dalam (Fonna, 2019), keterampilan dibagi menjadi dua bagian. Pertama adalah keterampilan tingkat rendah yang penting dalam proses pembelajaran, yaitu 
mengingat (remembering), memahami (understanding), dan menerapkan (applying), dan kedua adalah yang diklasifikasikan ke dalam keterampilan berpikir tingkat tinggi berupa keterampilan menganalisis (analysing), mengevaluasi (evaluating), dan mencipta (creating) sebagaimana Gambar 2.

\begin{tabular}{|c|c|c|c|}
\hline \multicolumn{3}{|c|}{ PROSES KOGNITIF } & DEFINISI \\
\hline C1 & \multirow{3}{*}{$\begin{array}{l}\mathrm{L} \\
\mathrm{O} \\
\mathrm{T} \\
\mathrm{S}\end{array}$} & Mengingat & $\begin{array}{l}\text { Mengambil pengetahuan yang relevan dari } \\
\text { ingatan }\end{array}$ \\
\hline $\mathrm{C} 2$ & & Memahami & $\begin{array}{l}\text { Membangun arti dari proses pembelajaran, } \\
\text { termasuk komunikasi lisan, tertulis, dan gambar }\end{array}$ \\
\hline C3 & & $\begin{array}{l}\text { Menerapkan/ } \\
\text { Mengaplikasikan }\end{array}$ & $\begin{array}{l}\text { Melakukan atau menggunakan prosedur di } \\
\text { dalam situasi yang tidak biasa }\end{array}$ \\
\hline C4 & $\mathrm{H}$ & Menganalisis & $\begin{array}{l}\text { Memecah materi ke dalam bagian-bagiannya dan } \\
\text { menentukan bagaimana bagian-bagian itu } \\
\text { terhubungkan antarbagian dan ke struktur atau } \\
\text { tujuan keseluruhan }\end{array}$ \\
\hline C5 & $\begin{array}{l}\mathrm{O} \\
\mathrm{T}\end{array}$ & $\begin{array}{l}\text { Menilai/ } \\
\text { Mengevaluasi }\end{array}$ & $\begin{array}{l}\text { Membuat pertimbangan berdasarkan kriteria atau } \\
\text { standar }\end{array}$ \\
\hline C6 & S & $\begin{array}{l}\text { Mengkreasi/ } \\
\text { Mencipta }\end{array}$ & $\begin{array}{l}\text { Menempatkan unsur-unsur secara bersama-sama } \\
\text { untuk membentuk keseluruhan secara koheren } \\
\text { atau fungsional; menyusun kembali unsur-unsur ke } \\
\text { dalam pola atau struktur baru }\end{array}$ \\
\hline
\end{tabular}

Gambar 2 : Aspek keterampilan berpikir tingkat tinggi

Trend perkembangan revolusi industri 4.0 dan Society 5.0 saat ini sudah sangat pesat, mau tidak mau memaksa seluruh elemen yang ada untuk sesegera mungkin menyesuaikan diri agar tidak tergilas oleh perkembangan zaman. Demikian halnya dengan guru, yang harus merubah paradigma berfikir untuk selalu mengembangkan metode pembelajaran yang berorientasi pada proses kognitif yang semula hanya mengingat, memahami dan mengaplikasikan (LOTS) menjadi menganalisis, mengevaluasi sampai mencipta (HOTS) dengan memanfaatkan teknologi yang berkembang saat ini yaitu melalui media digital. Beberapa penelitian yang telah dilakukan mengenai penerapan metode pembelajaran yang berorientasi HOTS menunjukkan adanya peningkatan hasil kualitas belajar siswa. Hipotesis penelitian $\mathrm{H}_{0}$ adalah tidak adanya pengaruh signifikan implementasi metode HOTS dengan fasilitas media digital terhadap hasil belajar siswa sedangkan $\mathrm{H}_{1}$ adalah adanya pengaruh signifikan implementasi metode HOTS dengan fasilitas media digital terhadap hasil belajar siswa.

\section{Metode Penelitian}

Penelitian ini merupakan jenis penelitian kuantitatif eksperimen yang menggunakan sampel, dilaksanakan pada satu kelas eksperimen. Kelas eksperimen adalah kelas yang diberikan perlakuan (treatment) khusus, yakni dengan memberikan pendampingan guru yang mendapatkan pembimbingan pembelajaran dengan model pembelajaran Higher Order Think Skill (HOTS) melalui pendekatan teknologi media belajar digital yang dilakukan secara online dan offline. Desain eksperimen pada penelitian ini menggunakan bentuk Pre-Eksperimental Design dengan tipe One Group Pre-test dan Post-test Design. Pada penelitian ini dilakukan ujian pre-test sebelum pembelajaran dimulai. Kemudian, kelas yang menjadi sampel diberikan perlakuan yaitu berupa penggunaan model pembelajaran HOTS melalui pendekatan teknologi secara offline dan online dalam kelas. Pada akhir pembelajaran siswa diberikan tes akhir (post test) berupa tes tertulis untuk mengetahui hasil belajar siswa. Dengan demikian hasil perlakuan dapat diketahui lebih akurat, karena dapat membandingkan dengan keadaan sebelum diberi perlakuan. Dengan adanya treatment model pembelajaran HOTS yang diterapkan di kelas diharapkan mampu menjadikan siswa untuk lebih berfikir kritis tentang apa yang terjadi di dunia luar sehingga mampu untuk menghadapi era dimana terjadinya transisi antara revolusi industry 4.0 dengan era society 5.0 uyang sberkembang saat ini. Menurut (Setyosari, 2012), desain ini dapat digambarkan sebagaimana Gambar 3. 


$$
\mathrm{O}_{1} \rightarrow \mathrm{O}_{2}
$$

Gambar 3. Desain Penelitian

Keterangan : $\quad 0_{1}=$ nilai pre test

$\mathrm{O}_{2}=$ nilai post test

Instrumen penelitian adalah suatu alat yang digunakan untuk mengukur fenomena alam maupun sosial yang diamati. Secara spesifik semua fenomena ini disebut variabel penelitian (Sugiyono, 2010). Adapun instrument penelitian yang digunakan dalam penelitian ini yang berfungsi sebagai alat pengumpul data adalah instrument soal pre test dan post test.

\section{Hasil dan Pembahasan}

Pendekatan yang dilakukan untuk menguji apakah instrumen soal baik soal pre test dan soal post test menunjukkan hasil yang konsisten apabila dilakukan pengukuran secara berulang-ulang adalah dengan menghitung koefisien alpha (Cronbach's alpha) untuk setiap variabel yang diukur. Dengan nilai koefisien alpha untuk pengukuran reliabilitas $>0.70$. Pengujian validitas dilakukan untuk mengetahui apakah instrumen soal yang digunakan benar-benar handal dan sahih untuk digunakan sebagai alat ukur. Pendekatan yang dilakukan untuk menguji apakah instrumen pertanyaan menunjukkan hasil yang konsisten apabila dilakukan pengukuran secara berulang-ulang adalah dengan menghitung koefisien alpha (Cronbach's alpha) untuk setiap variabel yang diukur. Pengujian reliabilitas dari penelitian ditunjukkan pada Table 1 dan 2.

Tabel 1. Hasil Pengujian Reliabilitas Soal Pretest

\begin{tabular}{cccc}
\hline Variabel & Cronbach' Alpha & Batasan & Keterangan \\
\hline Bahasa Indonesia & 0,714 & 0,70 & Reliabel \\
Matematika & 0,818 & 0,70 & Reliabel \\
Bahasa Inggris & 0,764 & 0,70 & Reliabel \\
IPA & 0,824 & 0,70 & Reliabel \\
\hline
\end{tabular}

Tabel 2. Hasil Pengujian Reliabilitas Soal Posttest

\begin{tabular}{cccc}
\hline Variabel & Cronbach' Alpha & Batasan & Keterangan \\
\hline Bahasa Indonesia & 0,725 & 0,70 & Reliabel \\
Matematika & 0,815 & 0,70 & Reliabel \\
Bahasa Inggris & 0,725 & 0,70 & Reliabel \\
IPA & 0,785 & 0,70 & Reliabel \\
\hline
\end{tabular}

Berdasarkan hasil perhitungan SPSS For Windows diatas, semua nilai Cronbach's Alpha lebih besar dari standart yang telah ditentukan yaitu $(>0.70)$ oleh karena itu dapat disimpulkan bahwa instrumen penelitian reliabilitas, jadi dapat disimpulkan bahwa soal yang digunakan untuk pretest dan postest dinyatakan handal atau dapat dipercaya sebagai alat ukur variabel. 


\section{Hasil Uji Validitas dan Uji t}

Dari hasil pengamatan, kemampuan dan pemahaman guru terhadap metode pembelajaran dengan model HOTS di SMPN 7 Halmahera Barat belum begitu baik. Penerapan pembelajaran berbasis HOTS merupakan pembelajaran berbasis masalah (problem based learning), dan penyelidikan kelompok (group investigation) yang mengarahkan kemampuan siswa untuk berpikir secara kritis pada sekolah menengah pertama lebih cepat dalam menerima berbagai jenis informasi, berpikir kreatif dalam memecahkan suatu masalah menggunakan pengetahuan yang dimiliki serta membuat keputusan dalam situasisituasi yang kompleks. Dalam hal ini para guru masih kesulitan dalam penyampaian dan pemahaman bagaimana menyusun soal HOTS yang, mencakup (1) drawing conduction (2) defining (3) analyzing (4) integrating (5) organizing (6) constructing (7) structuring (8) restructuring (9) finding patterns (10) finding underlying assumption (11) predicting (12) formulating hypothesis (13) establishing criteria (14) verifying and (15) applying dan critical, logical, reflective, metacognitive and creative thinking (Mainali, 2012). Para guru masih memerlukan waktu lebih lama untuk berlatih dan mengkaji teori-teori terkait dengan penyusunan soal HOTS. Oleh karena itu, untuk kelas eksperimen para guru tersebut mendapatkan pendampingan dari mentor mengenai implementasi HOTS ini dengan memanfaatkan media belajar digital baik secara online maupun offline.

Berikut hasil pre-test dan post-test dari siswa kelas IX A dan IX B sebagaaimana Gambar 4 dan Gambar 5.

\begin{tabular}{|c|c|c|c|c|c|c|c|c|c|c|c|c|c|c|c|}
\hline \multirow{2}{*}{$\begin{array}{c}\text { Siswa } \\
\text { dengan } \\
\text { no. } \\
\text { absen }\end{array}$} & \multicolumn{5}{|c|}{ Nilai Pre-test } & \multicolumn{5}{|c|}{ Nilai Tes formatif 1} & \multicolumn{5}{|c|}{ Kenaikan Progress } \\
\hline & Ind & Mat & Ing & IPA & Total & Ind & Mat & Ing & IPA & Total & Ind & Mat & Ing & IPA & Total \\
\hline 1 & 30 & 6 & 15 & 16 & 15.08 & 30 & 20 & 30 & 20 & 40 & $-38 \%$ & 6796 & $25 \%$ & -3896 & 5396 \\
\hline 2 & 15 & 12 & 15 & 4 & 10.35 & 30 & 20 & 30 & 20 & 40 & 2596 & $-17 \%$ & $25 \%$ & $150 \%$ & 12296 \\
\hline 3 & 22.5 & 16 & 20 & 14 & 16.31 & so & $\circ$ & 20 & 30 & 40 & 3936 & $-100 \%$ & -3896 & $7 \%$ & 3996 \\
\hline 4 & 10 & 10 & 12.5 & 8 & 9.11 & 20 & 20 & 20 & 40 & 40 & 2596 & $\alpha 96$ & $0 \%$ & $150 \%$ & 14796 \\
\hline 5 & 32.5 & 4 & 20 & 10 & 14.96 & 20 & 20 & 20 & 40 & 40 & $-62 \%$ & 15096 & -3896 & $100 \%$ & 5996 \\
\hline 6 & 20 & 8 & 75 & 8 & 9.79 & so & 30 & 30 & 20 & 52 & 5696 & 8896 & $150 \%$ & $25 \%$ & 2049 \\
\hline 7 & 17.5 & 8 & 17.5 & 10 & 11.93 & 10 & 30 & 40 & 10 & 36 & $-64 \%$ & $88 \%$ & $43 \%$ & -5096 & 7496 \\
\hline 8 & 22.5 & 8 & 17.5 & 16 & 14.40 & 30 & 30 & 10 & 20 & 36 & $-17 \%$ & 8896 & -6496 & -3896 & 4396 \\
\hline 9 & 22.5 & 10 & 10 & 8 & 11.36 & 40 & 20 & 30 & 20 & 44 & 1196 & $\alpha 6$ & $88 \%$ & $25 \%$ & 1229 \\
\hline 10 & 27.5 & 6 & 22.5 & 12 & 15.30 & 30 & 40 & 20 & 20 & 44 & $-32 \%$ & 23396 & -4496 & -1796 & 6996 \\
\hline 11 & 22.5 & 6 & 22.5 & 10 & 13.73 & so & 40 & 0 & so & 56 & 3936 & 23396 & -10096 & $150 \%$ & 13996 \\
\hline 12 & 17.5 & 12 & 22.5 & 6 & 13.05 & 20 & 40 & 70 & 30 & 64 & $-29 \%$ & 6796 & $94 \%$ & $150 \%$ & 18496 \\
\hline 13 & 25 & 2 & 12.5 & 4 & 9.79 & 40 & 20 & 40 & 20 & 48 & 096 & 40036 & $100 \%$ & $150 \%$ & $196 \%$ \\
\hline 14 & 12.5 & 16 & 15 & 10 & 12.04 & 30 & 30 & 20 & 40 & 48 & 5096 & $-6 \%$ & -1796 & $100 \%$ & 1229 \\
\hline 15 & 22.5 & 6 & 17.5 & 10 & 12.60 & so & 30 & 30 & 10 & 48 & 3996 & 15096 & $7 \%$ & -5036 & 12296 \\
\hline 16 & 32.5 & 8 & 15 & 8 & 14.29 & 40 & 20 & so & 40 & 60 & $-23 \%$ & 2596 & $108 \%$ & $150 \%$ & 14796 \\
\hline 17 & 10 & 4 & 10 & 8 & 7.20 & 20 & 20 & 10 & 30 & 32 & 2596 & $150 \%$ & -3896 & $88 \%$ & 1549 \\
\hline 18 & 20 & 6 & 10 & 14 & 11.25 & 40 & 10 & 0 & 40 & 36 & 2596 & $-17 \%$ & -10096 & $43 \%$ & 829 \\
\hline 19 & 12.5 & 6 & 20 & 10 & 10.91 & so & 20 & 40 & 10 & 48 & 15036 & 6796 & $25 \%$ & -5036 & 15496 \\
\hline 20 & 30 & 0 & 22.5 & 12 & 14.51 & so & 30 & 10 & 20 & 44 & 496 & 096 & -7296 & -1796 & 819 \\
\hline 21 & 25.0 & 4.0 & 10.0 & 4.0 & 9.68 & 40 & 50 & 40 & 30 & 64 & 6096 & 115096 & $300 \%$ & $650 \%$ & 5619 \\
\hline 22 & 22.5 & 4.0 & 25.0 & 12.0 & 14.29 & 30 & 30 & 30 & 10 & 40 & 3396 & 65096 & $20 \% 6$ & -1736 & 18096 \\
\hline 23 & 22.5 & 6.0 & 15.0 & 12.0 & 12.49 & 40 & 20 & 20 & 10 & 36 & 7896 & 23396 & $33 \%$ & -1796 & 1889 \\
\hline 24 & 27.5 & 4.0 & 20.0 & 14.0 & 14.74 & 40 & 30 & 20 & 10 & 40 & 4596 & 65096 & $0 \%$ & -2996 & 1719 \\
\hline 25 & 27.5 & 14.0 & 12.5 & 14.0 & 15.30 & 40 & 30 & 40 & 40 & 60 & 4596 & 11496 & $220 \%$ & $186 \%$ & 29296 \\
\hline \multicolumn{5}{|c|}{ Rata-rata pre-test } & 12.9 & Rat & -Rata & tes fo & matif & 45.4 & \multicolumn{4}{|c|}{ Rata-rata progres } & $148 \%$ \\
\hline
\end{tabular}

Gambar 4. Pre-Test dan Post-Test Dari Siswa Kelas IX A 


\begin{tabular}{|c|c|c|c|c|c|c|c|c|c|c|c|c|c|c|c|}
\hline \multirow{2}{*}{$\begin{array}{c}\text { Siswa } \\
\text { dengan } \\
\text { no. } \\
\text { absen }\end{array}$} & \multicolumn{5}{|c|}{ Nilai Pre-test } & \multicolumn{5}{|c|}{ Nilai Tes formatif 1} & \multicolumn{5}{|c|}{ Kenaikan Progress } \\
\hline & Ind & Mat & Ing & IPA & Total & Ind & Mat & Ing & IPA & Total & Ind & Mat & Ing & IPA & Total \\
\hline 1 & 35.0 & 4.0 & 12.5 & 12.0 & 14.29 & 70 & 20 & 30 & 20 & 56 & $100 \%$ & 40096 & 14036 & $67 \%$ & $292 \%$ \\
\hline 2 & 12.5 & 4.0 & 15.0 & 10.0 & 9.34 & 20 & 30 & 40 & 30 & 48 & 6096 & 65096 & 16796 & 20036 & $414 \%$ \\
\hline 3 & 17.5 & 6.0 & 22.5 & 8.0 & 12.15 & 20 & 30 & 20 & o & 28 & 1496 & 40096 & $-11 \%$ & $-100 \%$ & $130 \%$ \\
\hline 4 & 17.5 & 6.0 & 12.5 & 10.0 & 10.35 & so & 30 & 20 & 40 & 56 & $186 \%$ & 40096 & $60 \%$ & 30096 & $441 \%$ \\
\hline 5 & 12.5 & 10.0 & 17.5 & 10.0 & 11.25 & 60 & 30 & 20 & 20 & 52 & $380 \%$ & 20096 & $14 \%$ & 10036 & $362 \%$ \\
\hline 6 & 20.0 & 10.0 & 22.5 & 10.0 & 14.06 & 20 & 40 & 20 & 0 & 32 & $0 \%$ & $300 \%$ & $-11 \%$ & $-100 \%$ & $128 \%$ \\
\hline 7 & 17.5 & 8.0 & 15.0 & 4.0 & 10.01 & 60 & 0 & 30 & 0 & 36 & $243 \%$ & -10036 & 10096 & $-100 \%$ & $260 \%$ \\
\hline 8 & 22.5 & 6.0 & 10.0 & 8.0 & 10.46 & so & 20 & 0 & 20 & 36 & $122 \%$ & 23396 & $-100 \%$ & 15096 & $244 \%$ \\
\hline 9 & 25.0 & 8.0 & 17.5 & 2.0 & 11.81 & 20 & 30 & 30 & 0 & 32 & -2036 & $275 \%$ & $71 \%$ & $-100 \%$ & $171 \%$ \\
\hline 10 & 22.5 & 4.0 & 17.5 & 2.0 & 10.35 & 40 & 20 & 0 & 20 & 32 & 7896 & 40096 & $-100 \%$ & 90096 & $209 \%$ \\
\hline 11 & 25.0 & 18.0 & 15.0 & 8.0 & 14.85 & 40 & 30 & 20 & 40 & 52 & 6096 & $67 \%$ & $33 \%$ & 40036 & $250 \%$ \\
\hline 12 & 20.0 & 6.0 & 22.5 & 10.0 & 13.16 & so & 30 & 0 & 30 & 44 & $150 \%$ & 40096 & $-100 \%$ & 20096 & $234 \%$ \\
\hline 13 & 15.0 & 8.0 & 17.5 & 10.0 & 11.36 & 60 & 10 & 10 & 20 & 40 & $300 \%$ & $25 \%$ & $-43 \%$ & 10096 & $252 \%$ \\
\hline 14 & 27.5 & 2.0 & 10.0 & 12.0 & 11.59 & 40 & 20 & 40 & 10 & 44 & 4596 & 90096 & 30096 & $-17 \%$ & $280 \%$ \\
\hline 15 & 25.0 & 10.0 & 10.0 & 16.0 & 13.73 & 80 & 40 & 10 & 20 & 60 & $220 \%$ & 30096 & $0 \%$ & $25 \%$ & $337 \%$ \\
\hline 16 & 25.0 & 14.0 & 15.0 & 6.0 & 13.50 & 10 & 40 & 30 & 10 & 36 & -6036 & 18696 & 10036 & $67 \%$ & $167 \%$ \\
\hline 17 & 20.0 & 10.0 & 20.0 & 14.0 & 14.40 & so & 50 & 40 & 20 & 64 & $150 \%$ & 40096 & 10096 & $43 \%$ & $344 \%$ \\
\hline 18 & 22.5 & 4.0 & 17.5 & 12.0 & 12.60 & 30 & 20 & 10 & 20 & 32 & 3396 & 40096 & $-43 \%$ & $67 \%$ & $154 \%$ \\
\hline 19 & 35.0 & 8.0 & 12.5 & 12.0 & 15.19 & so & 30 & 20 & 0 & 40 & 4396 & 27596 & $60 \%$ & $-100 \%$ & $163 \%$ \\
\hline 20 & 22.5 & 6.0 & 22.5 & 10.0 & 13.73 & 30 & 30 & 30 & 10 & 40 & 3396 & 40096 & $33 \%$ & 096 & $191 \%$ \\
\hline 21 & 25.0 & 8.0 & 12.5 & 6.0 & 11.59 & so & 20 & 10 & 10 & 36 & $100 \%$ & 15096 & $-20 \%$ & $67 \%$ & $211 \%$ \\
\hline 22 & 17.5 & 120 & 20.0 & 12.0 & 13.84 & so & 10 & 20 & 20 & 40 & $186 \%$ & $-17 \%$ & 096 & $67 \%$ & $189 \%$ \\
\hline 23 & 22.5 & 8.0 & 25.0 & 14.0 & 15.64 & 40 & 10 & 40 & 20 & 44 & 7896 & $25 \%$ & $60 \%$ & $43 \%$ & $181 \%$ \\
\hline 24 & 25.0 & 6.0 & 17.5 & 12.0 & 13.61 & 40 & 20 & 40 & 10 & 44 & $60 \%$ & 23396 & 12936 & $-17 \%$ & $223 \%$ \\
\hline \multicolumn{5}{|c|}{ Rata-rata pre-test } & 12.6 & Rat & -Rata & tes fo & natif & 42.7 & \multicolumn{4}{|c|}{ Rata-rata progres } & $243 \%$ \\
\hline
\end{tabular}

\section{Gambar 5. Pre-Test dan Post-Test Dari Siswa Kelas IX B}

Treatment yang digunakan dalam kelas yaitu dengan menggunakan 254 video pembelajaran dan 278 quiz serta paket-paket latihan soal untuk mata pelajaran yang diujikan yaitu Bahasa Indonesia, Bahasa Inggris, Matematika dan IPA dengan mengintegrasikan fungsionalitas pembelajaran hybrid secara online dan offline. Para Guru yang mengajar di kelas sebelumnya mendapatkan materi yang mengusung tema penggunaan bahasa yang efektif dan komunikatif dan kontekstualisasi materi ajar. Penggunaan metode e-learning dengan ini dapat membantu guru dalam mengajar dan membuat kelas belajar menjadi lebih aktif dan interaktif, namun masih terbatas dengan ketersediaan sarana berupa komputer dan ponsel siswa. Pembelajaran siswa ini diikuti 49 siswa atau 2 rombongan belajar siswa kelas 9 SMPN 7 Halmahera Barat

Hasil rata-rata nilai pre-test mata pelajaran Bahasa indonesia yakni sebesar 22 dan hasil tes formatif diperoleh hasil sebesar 39 atau naik 62.21\%. Nilai pre-test mata pelajaran Matematika diperoleh hasil sebesar 7.6 dan hasil tes formatif sebesar 26 atau naik $231 \%$. Nilai pre-test mata pelajaran Bahasa Inggris diperoleh hasil sebesar 16.5 dan hasil tes formatif diperoleh hasil sebesar 24.4 atau naik 34\%. Mata pelajaran IPA diperoleh hasil pre-test sebesar 9.9 dan hasil tes formatif diperoleh hasil sebesar 20.8 atau naik $83 \%$. Sedangkan untuk hasil penilaian pre-test secara umum diperoleh rata-rata nilai sebeasar 12.6 dan rata-rata nilai tes formatif sebesar 44.08 atau mengalami kenaikan sebasar $194.61 \%$.

Pengujian validitas dilakukan untuk mengetahui apakah instrumen pertanyaan yang digunakan benar-benar handal dan sahih untuk digunakan sebagai alat ukur. Dalam penelitian ini, pengujian validitas dilakukan dengan menghitung nilai pearson correlation menggunakan SPSS For Windows. Tabel di bawah ini menunjukan bahwa seluruh variabel untuk soal pre test dan post test menunjukkan indeks pearson correlation yang lebih dari $>0,05$. Hal ini dapat disimpulkan semua variabel dinyatakan valid.

Setelah itu, digunakan uji-t paired untuk membandingkan rata-rata dua grup yang saling berpasangan dengan koresponden tetap, yakni nilai pre test kelas sebelum diberikan 
treatment dan nilai post-test kelas setelah diberikan treatment. Rumus $\mathrm{t}$ yang digunakan untuk sampel yang berpasangan. Pengujian dengan uji-t dilakukan dengan bantuan program SPSS For Windows. Berikut hasil uji t terhadap 2 kelas eksperiman.

Dari hasil uji-t yang dilakukan dengan $\alpha=0.05$ atau tingkat signifikansi $5 \%$, diperoleh hasil untuk kelas IX A untuk 4 mata pelajaran yang di uji cobakan, diperoleh hasil $t_{\text {hitung }}$ untuk Bahasa Indonesia sebesar 5.84, Matematika 7.75, Bahasa Inggris 3.18 dan IPA 5.73, dengan $t_{\text {table }}$ sebesar 2.06. Pada tabel diatas, $t_{\text {stat }}$ sebagai $t_{\text {hitung }}$ dan $t_{\text {critical two-tail }}$ sebagai $t$ tabe, sehingga diperoleh $t$ hitung $>t$ table, $\mathrm{H}_{0}$ ditolak dan $\mathrm{H}_{1}$ diterima, artinya ada pengaruh signifikan di kelas eksperimen sebelum diberikan treatment metode HOTS menggunakan media belajar digital sebelum dan setelah diberikan treatment tersebut yang dilihat dari hasil pre-test dan post-test siswa di kelas IX A. Hasil yang sama diperoleh di kelas IX B, dengan hasil t hitung untuk 4 mata pelajaran yang diuji cobakan, diperoleh hasil $t_{\text {hitung }}$ untuk Bahasa Indonesia sebesar 5.81, Matematika 7.96, Bahasa Inggris 2.98 dan IPA 2.87, dengan $t_{\text {table }}$ sebesar 2.06, sehingga diperoleh $t$ hitung $>t_{\text {table }}, \mathrm{H}_{0}$ ditolak dan $\mathrm{H}_{1}$ diterima, artinya ada pengaruh signifikan di kelas eksperimen sebelum diberikan treatment metode HOTS menggunakan media belajar digital sebelum dan setelah diberikan treatment tersebut yang dilihat dari hasil pre-test dan post-test siswa kelas IX B.

\section{Kesimpulan}

Model pembelajaran berorientasi Higher Order Think Skill (HOTS) melalui pendekatan teknologi bekerja sama dengan platform digital sebagai media bantu diimplementasikan di SMP Negeri 7 di kabupaten Halmahera Barat, melibatkan 49 orang siswa. Berdasarkan hasil rata-rata nilai pre-test mata pelajaran Bahasa Indonesai naik dari 22 menjadi 39 atau naik 62.21\%. Nilai pre-test mata pelajaran Matematika dari 7.6 menjadi 26 atau naik 231\%. Mata pelajaran Bahasa Inggris naik dari 16.5 menjadi 24.4 atau kenaikan 34\%. Dan nilai mata pelajaran IPA dari 9.9 menjadi 20.8 atau naik 83\%. Sedangkan untuk hasil penilaian pre-test secara umum diperoleh rata-rata nilai sebesar 12.6

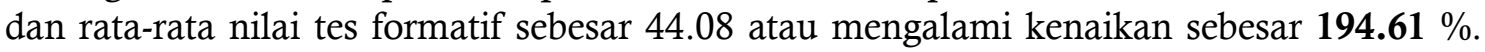
Dari hasil uji-t yang dilakukan dengan $\alpha=0.05$ atau tingkat signifikansi $5 \%$, diperoleh hasil baik untuk kelas IX A dan IX B untuk 4 mata pelajaran yang di uji cobakan, yakni Bahasa Indonesia, Matematika, Bahasa Inggris dan IPA diperoleh hasil $t_{\text {hitung }}>t$ table, sehingga $\mathrm{H}_{0}$ ditolak dan $\mathrm{H}_{1}$ diterima, artinya ada pengaruh signifikan di kelas eksperimen sebelum diberikan treatment metode HOTS menggunakan media belajar digital sebelum dan setelah diberikan treatment. Kenaikan prestasi belajar siswa sangat signifikan, menunjukkan bahwa model ini layak direkomendasikan untuk direplikasi di daerah tertinggal dan terpencil lain, yang mengalami kendala sangat minimnya sarana dan prasarana pendidikan dan tenaga guru.

Pada kelas eksperimen, para guru mendapatkan pendampingan/ pelatihan mengenai implementasi HOTS memanfaatkan media belajar digital baik secara online maupun offline. Dengan adanya pendidikan yang berbasis HOTS ini menjadikan siswa pada tingkat menengah pertama lebih berpikir kritis dan terbuka terhadap perkembangan dunia luar. Hal ini sebagai salah satu strategi peningkatan literasi teknologi kepada guru dan siswa, mendukung antisipasi penyediaan sumber daya manusia daerah tertinggal era industri 4.0 .

\section{Referensi}

Direktorat Pembinaan SMK Kementerian Pendidikan dan Kebudayaan. (2018). Peningkatan Proses Pembelajaran dan Penilaian Pembelajaran Abad 21 Dalam Meningkatkan Kualitas Pembelajaran SMK. Jakarta: Direktorat Pembinaan Sekolah Menengah Kejuruan Direktorat Jenderal Pendidikan Dasar dan Menengah Kementerian Pendidikan dan Kebudayaan. 
Fadel, C. (2008, May). Partnership For 21st Century Skills. Retrieved Oktober 1, 2019, from https://www.oecd.org

Fonna, N. (2019). Pengembangan Revolusi Industri 4.0 dalam Berbagai Bidang. Medan: Guepedia.com.

Mainali, P. B. (2012). Higher Thinking Order in Educarion. Academic Voices A Mutidisciplinary Journal Volume 2, 5-10.

Ristekdikti. (2018). http://sumberdaya.ristekdikti.go.idera-revolusi-industri-4-0-saatnya-generasimillennial-menjadi-dosen-masa-depan. Retrieved october 2, 2019, from http://sumberdaya.ristekdikti.go.id

Setyosari, P. (2012). Metode Penelitian Pendidikan dan Pengembangan. Jakarta: Kencana Prenada Media Grup.

Walters, R. (2018). Salary Survey 2018 Greater China\&South East Asia. London: Robert Walters Plc. 